\title{
Think first or just do writing?
}

\author{
Lucky Rahayu Nurjamin ${ }^{1}$, Yustika Nur Fajriah ${ }^{2}$, Irsyad Nugraha ${ }^{3}$, Anne Ratna Suminar ${ }^{4}$ \\ \{luckyrahayu@institutpendidikan.ac.id ${ }^{1}$, yustikanurfajriah@institutpendidikan.ac.id ${ }^{2}$, \\ irsyadnugraha@institutpendidikan.ac.id $\left.{ }^{3}\right\}$ \\ Institut Pendidikan Indonesia, Jl. Pahlawan No.32 Sukagalih Tarogong Kidul, Garut, Indonesia
}

\begin{abstract}
In response to the problematic educational policy related to an EFL curriculum, there must be explicit techniques to use, particularly the techniques in teaching writing. In accordance, this study is aimed to examine the effective technique in teaching writing by comparing the two; think-talk-write (TTW) and fast writing techniques. This quantitative study was deployed in terms of quasi-experimental design. The data were collected through the test and conducted in one suburban junior high school in Indonesia involving $2502^{\text {nd }}$ year students as the population and 46 sample students. In conclusion, the result statistically reveals that $82 \%$ students in TTW class reached the passing grade. Meanwhile, those who were taught under fastwriting were only $42 \%$. Hence, think-talk-write is more effective than fastwriting technique. Therefore, the policy maker should explicitly state on the EFL curriculum that think-talk-write is the recommended technique applied by higher education level while fast writing is for lower education level.
\end{abstract}

Keywords: Educational policy, EFL Curriculum, Fastwriting, Think-talk-write, Writing

\section{Introduction}

Educational policy in a country is formerly set based on the characteristics of the local society. The policy covers the social characteristics involving socio-cultural factors, identity, needs, and etc [1]. One of the socio-cultural aspect needed is a language, particularly the language used for global communication. In regard, the language used for global communication is English.

Since it is significance, English is set as the foreign language for Indonesian which is obliged to acquire [2][3]. This becomes the requirement to graduate from junior and senior high school [4][2]. In regard, English has been the compulsory subject started from junior high school. In relation to its compulsory, there should be a curriculum which mention explicitly the use of specific strategies properly used. This means that curriculum, as a part of educational policy, should sounds such effective strategies in teaching English, especially the four skills; listening, speaking, reading, and writing. This due to the support of teacher in teaching effectively.

Seeing this, measuring the quality of such specific strategies which properly applied should be prepared [5][6]. As one of the crucial role, there are various types of writing strategy which need to compare. In this case, the problematic strategies to compare are Think Talk Write and Fast-writing. Both are becoming problematic since there is no detail information related to what context effectively applied.

Think talk write, firstly proposed, builds in time for thought and reflection and for the organization of ideas and the testing of choose ideas before students are expected to write [7]. 
In compare, fast writing is one of technique to write a text in a short time [8]. This technique teaches students to be faster and able to pour things out of their mind without thinking first. Thus, the point is 'do we need to think or just do writing quickly'.

\section{Method}

This quasi-experimental study covered the experimental group A and B. The design was adapted from Creswell which set the achievement test as the instrument in collecting the data [9]. This test was employed to measure the students' achievement in writing skill before and after they taught by fastwriting and Think-Talk-Write (TTW) technique. It was conducted in one suburban junior high school in one of EFL setting, Indonesia, involving $2502^{\text {nd }}$ year students as the population and 46 sample students.

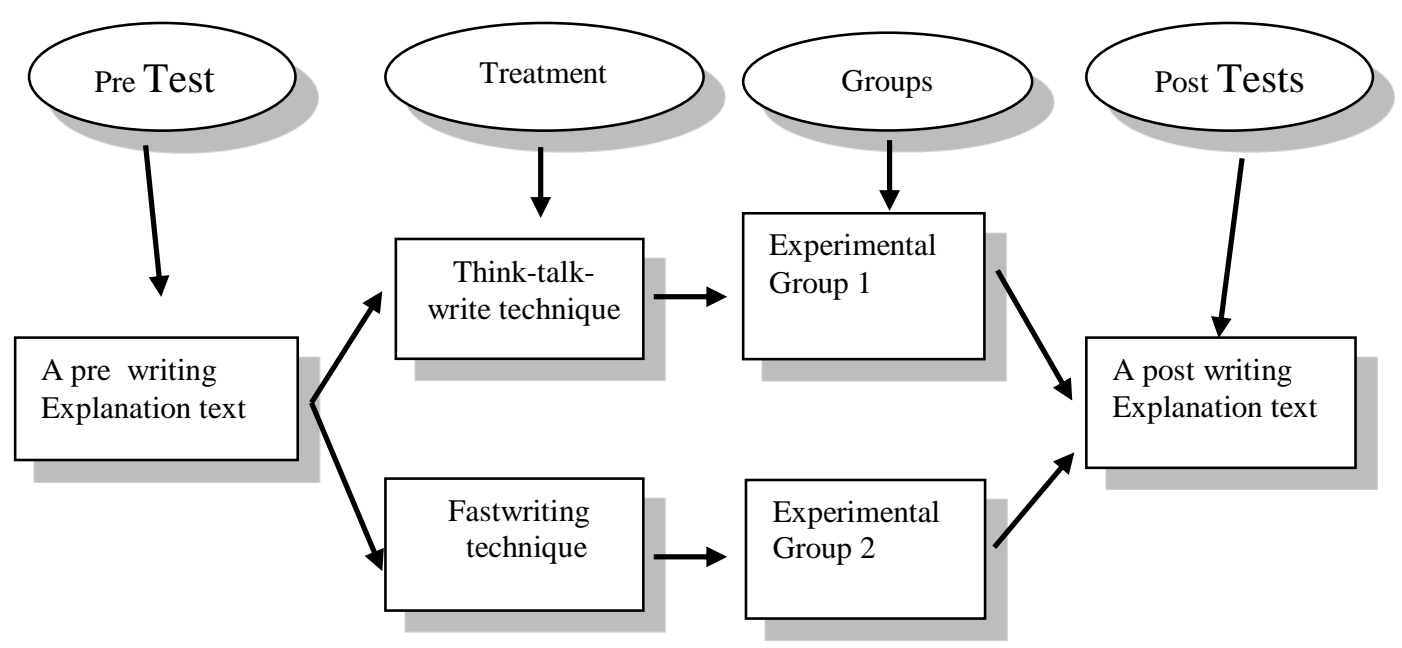

Figure 1. Quasi-Experimental Design Adapted from Creswell 2012

\section{Results}

From the four meetings of treatment, it appears that the results of writing students using techniques of think-talk-write techniques are better than those using fastwriting techniques. It can be known from posttest result, it turns out that both groups have different scores, the average score of post-test in experimental class is 83.26 with standard deviation 5.96. while the average score of post-test in control class is 77.35 with standard deviation 4.37. Furthermore, the analysis of Mann Whitney test shows $Z_{\text {observed }}<Z_{\text {critical }}(-3,6806<1,65)$. this means think-talkwrite technique is more effective than fastwriting technique.

Furthermore, the normalized gain of the experimental class is 0.47 and the standard deviation is 0.15 with a midlle interpretation. While the average score of the normalized gain 
control class of 0.43 and standard simplex 0.13 with a midlle interpretation. The average value of the experimental class is greater than the control class, the analysis obtained the conclusion that the ability to write between students who get the method of think talk-write better than those using fastwriting techniques.

Since this study aims to determine which technique is more effective, then it tested the comparison between posttest results and the value of minimum score. The test showed that the think-talk-write class reached $82 \%$ with the completed criteria, while the fastwriting class only reached $48 \%$ with the completed the minimum score. This means, the percentage of students in think-talk-write class is greater than the students using fastwriting technique. Based on the results of the hypothesis that $\mathrm{H}_{0}$ is accepted, the technique of think-talk-write is more effective than fastwriting technique.

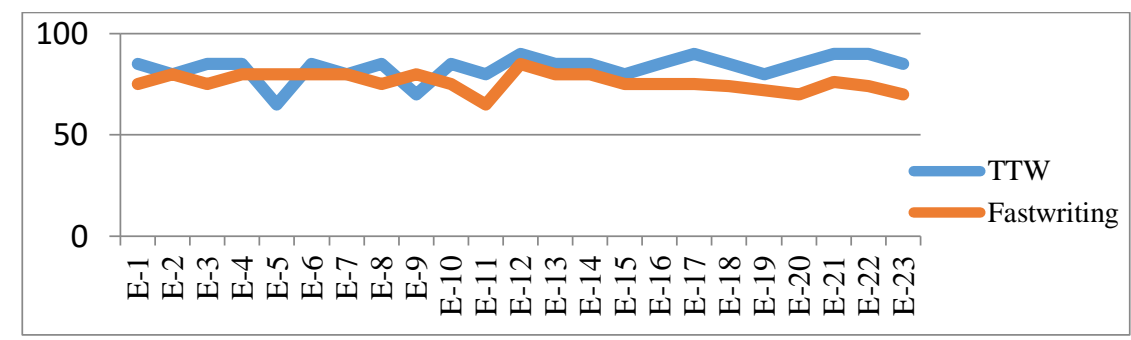

Figure 2. Students' Score of Writing

\section{Discussion}

In regard to the result, another significant part is the quality of writing involving writing characteristics made in both classes. First, the writing characteristics appear in think talk write tended to be shorter than fastwriting. Second, think talk write need a longer time process. Third, think talk write focused on one specific point.

Particularly, writing using think talk write produced a better quality of writing. This is seen from the aspects of topic, generic structure, and linguistic features applied [10][11]. Mostly, they tended to choose one topic and do the outlining before their writing. It is because they had a spare time to think and discuss what they read. However, thinking and discussing spent more times which means the time for writing became shorter. As the implication, most of their writings were short and straight to the point.

On the other side, fastwiriting triggered the students to spill out what they have just read. Since there is no explicitly given a time for thinking, the students wrote as many as possible [12]. This positively support the students write freely without any hesitation [13][14]. However, their writing tended to be low in terms of quality since they trapped in spilling out the idea rather than the focus topic, generic structure, and linguistic features of genre they write.

\section{Conclusion}

As the conclusion, the use think-talk-write technique in teaching writing explanation text is more effective than fastwriting technique. It is concluded that the students' writing 
improvement by think-talk-write technique is greater than fastwriting technique. Think-talkwrite is seen effectively applied for the higher level students who are focusing on the quality of writing. On the other hand, fastwriting is indicated proper for the students in the lower level since it supports the students to write everything they know from their reading.

As the implication, the educational policy, particularly an EFL curriculum, should consider to explicitly state that think-talk-write is one of the priority technique to be applied in the higher level education. Put differently, fastwriting should be categorised as one of the recommended strategy to be applied in the lower level education. This presumably assist EFL teacher to teach writing effectively.

\section{References}

[1] Bautista, T.: Language planning and policies in the developing nations. The National Center for Teacher Education Research. Philippine Normal University Research (thesis) (2017)

[2] Hadisantosa, N.: Insights from Indonesia. In R. Johnstone (Ed.). Learning through english: Policies, challenges and prospects. London: British Council. Vol., pp. 24-46 (2010)

[3] Lauder, A. The status and function of English in Indonesia: a review of key factors. Makara, Social Humaniora. Vol. 12., pp. 9-20 (2008)

[4] Zein, S.: Language in education policy on Primary EFL: the case of Indonesia. Int. J. of Pedagogies \& Learning. Vol. 12., pp. 133-146 (2017)

[5] Harmer, J. How to Teach Writing. London: Stenton Associates. (2007)

[6] Reid, J. M. Teaching ESL Writing. USA: Prentice Hall Regents. (1993)

[7] Huinker, D. dan Laughlin, C. Talk You Way into Writing. in. P. C. Elliot and M.J. Kenney (Eds). Years Book 1996. Communication in Mathematics K-12 and Beyond. USA:NCTM. (1996)〉

[8] Fryxell, David A. Write Faster, Write Better. Cincinnati, Ohio: Writer's Digest Books. (2004)

[9] Creswell, J.C. Education Research, Planning, Conducting and Evaluating Quantitative and Qualitative Research. 4th edition. Boston: Pearson. (2012)

[10] Hyland, Ken. Second Language Writing. New York : Cambridge University Press. (2003)

[11] Hyland, Maureen. Exploring Text Types. New York: R.I.C Publication. (2003)

[12] De Porter, Bobby \& Hernacki, M. Quantum Learning: Membiasakan BelajarNyaman dan Menyenangkan. Bandung: Kaifa. (2001)

[13] Westwood, P. S. What teachers need to know about teaching methods. Melbourne: Australian Council for Educational Research. (2008)

[14] Musthafa, B.: Teaching English to young learners in Indonesia: Essential requirements. Educationist. Vol. 4., pp. 120-125 (2010) 